\title{
Carbon Ligands: From Fundamental Aspects to Applications
}

\author{
Yves Canac (D)
}

Citation: Canac, Y. Carbon Ligands: From Fundamental Aspects to

Applications. Molecules 2021, 26, 2132. https: / / doi.org/10.3390/

molecules 26082132

Received: 1 April 2021

Accepted: 6 April 2021

Published: 8 April 2021

Publisher's Note: MDPI stays neutral with regard to jurisdictional claims in published maps and institutional affiliations.

Copyright: (C) 2021 by the author. Licensee MDPI, Basel, Switzerland. This article is an open access article distributed under the terms and conditions of the Creative Commons Attribution (CC BY) license (https:// creativecommons.org/licenses/by/ $4.0 /)$.
LCC-CNRS, Université de Toulouse, CNRS, UPS, CEDEX 4, 31077 Toulouse, France; yves.canac@lcc-toulouse.fr

Ligand design is at the forefront of many advances in various areas of chemistry such as organometallic chemistry, functional materials, and homogeneous catalysis. Faced with these challenges, the development of ligands has long been centered on elements of group $15(\mathrm{~N}, \mathrm{P})$, and it is only more recently that carbon ligands have proven to be valuable alternatives. The predominance of $\mathrm{N}$ - and P-based ligands for many years was due to their high stability, as opposed to carbon ligands, which were supposed to be highly sensitive and reactive. The isolation of the first stable carbenes, namely, a phosphino(silyl)carbene by Bertrand et al. in 1988 [1], followed a few years later by the famous $N$-heterocyclic carbenes (NHCs) by Arduengo and co-workers [2] proved thus to be a trigger in the minds of chemists, leading very quickly to remarkable advances in both fundamental and applied fields of chemistry. However, if the advent of carbenes was a decisive factor, other carbon ligands demonstrated also their potential as Lewis bases in the activation of inert bonds, coordination chemistry, and homogeneous catalysis. Indeed, one must also mention the huge contribution of Schmidbaur in the chemistry of P-ylides which brought these carbon species to light [3]. Later on, different carbon ligands were developed based on a C-sp $p^{2}$ coordinating carbon atom similar to NHCs or, alternatively, on a C-sp ${ }^{3}$ coordinating carbon atom similar to phosphonium ylides. In the first category, we can mention the more recently reported cyclic alkylamino carbenes (CAACs) where one of the stabilizing $\mathrm{N}$-atoms adjacent to the carbenic center is substituted by a quaternary carbon atom [4], and in the second category all other onium ylides in which the positively charged heteroatom is an N, As, S, or Se atom [5] without forgetting the N-heterocyclic olefins (NHOs) where the exocyclic ylidic carbon atom is stabilized by an imidazolium moiety [6]. Following Ramirez's pioneering report on carbodiphosphoranes [7], bis-ylide species also named carbones [8], which behave like strong $\sigma$ - and $\pi$-donor carbon ligands due to the presence of two lone pairs at the central carbon atom, have also recently experienced a renewed interest in coordination chemistry with applications in catalysis [9]. While all the carbon ligands cited so far have the common feature of being globally neutral in their free state, anionic carbon ligands likewise play a fundamental role in modern chemistry. Both NHCs and ylides can be thus made anionic by deprotonation to form metalated dicarbenes and ylides which correspond to ditopic anionic NHCs [10] and yldiides [11], respectively. In these species, the introduction of a negative charge modifies the electronic properties resulting in an enhancement of the nucleophilicity with repercussions, in particular, in catalysis. Other anionic carbon ligands exhibiting alkyl, alkenyl, alkynyl, allyl, aryl, or cyclopentadienyl-based backbones differing in the hybridization state and the number of coordinating carbon atoms were also widely considered over the years from fundamental aspects to applications.

In this Special Issue, the majority of the different types of carbon ligands mentioned above have been gathered together. The NHCs which constitute the most developed family of neutral carbon ligands have been approached from two main directions by the different contributors, namely, from a synthetic point of view with the preparation of new carbenic structures, and for their applications either in catalysis or in biology. In the first direction, while Kunz et al. described the fascinating coordination chemistry of a strongly donor macrocyclic C,N,C-pincer ligand exhibiting pentamethylene tethered 
NHC donor ends [12], Dias et al. were interested in the design of $\mathrm{Hg}(\mathrm{II})$ complexes bearing anionic maloNHC ligands [13], and Santini et al. in the chemistry of zwitterionic imidazolium borate species [14]. Regarding catalytic applications, Grela et al. reported the preparation of a family of nitro-activated $\mathrm{Ru}(\mathrm{II})$-based olefin metathesis catalysts while evaluating the influence of the NHC ligand [15]. Huc et al. demonstrated that benzyloxycalix arene supported NHC-Pd(II) complexes were active for the Suzuki-Miyaura cross-coupling reaction in water [16], and Le Roux et al. focused on the preparation of $\mathrm{Ti}(\mathrm{IV})$ and $\mathrm{Hf}(\mathrm{IV})$ complexes containing tridentate bis-phenolate NHC core ligands for the copolymerization of cyclohexene oxide with $\mathrm{CO}_{2}$ [17]. For biological purposes, BelleminLaponnaz et al. synthetized a series of $\mathrm{Pt}(\mathrm{IV}) \mathrm{NHC}$ complexes and studied their cytotoxicity against different cancer cell lines [18], and Gornitzka et al. prepared Au(I) NHC-artemether complexes to assess their antiplasmodial activity and cytotoxicity against mammalian cells [19]. Finally, in this category of $s p^{2}$-carbon ligands, the chemistry of NHC core pincer ligands bearing two anionic coordinating ends, especially phosphonium ylide moieties, was reviewed by us [20].

As a formal link between the two categories of neutral carbon ligands of interest, Gessner et al. reported a joint experimental and theoretical study on cyclic amino(ylide) carbenes based on pyrrole and trialkyl onium fragments where the carbenic center is expected to be stabilized by the strongly donating ylide substituent [21]. Bis-ylides were also considered, on the one hand by Sundermeyer et al. through the preparation of photoluminescent $\mathrm{Cu}(\mathrm{I})$ complexes of $P, C, P$-carbodiphosphorane-based ligands [22], and on the other hand by Maerten et al. with the coordinating behavior of phosphine-sulfoxide substituted carbones towards dichlorogermylene [23]. Those carbones, as well as carbido complexes featuring a naked carbon atom, were reviewed by Frenking et al. [24]. In the same family of carbon species characterized by the presence of a $s p^{3}$-carbon atom, selenonium ylides were described from synthetic and structural aspects to synthetic applications by Drabowicz et al. [25]. Anionic carbon ligands were also of primary interest in this issue, as illustrated with the report by Grützmacher et al. of alkaline metal salts based on trop $\left(\mathrm{C}_{5} \mathrm{H}_{11}\right)$ and $\operatorname{dbcot}\left(\mathrm{C}_{16} \mathrm{H}_{12}\right)$ moieties and the characterization of a $\mathrm{d}^{8}-\mathrm{Rh}(\mathrm{I})$ complex of the anionic trop ligand [26].

Funding: This research received no external funding.

Acknowledgments: The guest editor would like to thank all the authors that have contributed to this special issue and all the reviewers for the evaluation of the submitted articles.

Conflicts of Interest: The author declares no conflict of interest.

\section{References}

1. Igau, A.; Grutzmacher, H.; Baceiredo, A.; Bertrand, G. Analogous $\alpha, \alpha^{\prime}$-bis-carbenoid triply bonded species: Synthesis of a stable $\lambda^{3}$-phosphinocarbene- $\lambda^{5}$-phosphaacetylene. J. Am. Chem. Soc. 1988, 110, 6463. [CrossRef]

2. Arduengo III, A.J.; Harlow, R.L.; Kline, M. A stable crystalline carbene. J. Am. Chem. Soc. 1991, 113, 361. [CrossRef]

3. Schmidbaur, H. Phosphorus ylides in the coordination sphere of transition metals: An inventory. Angew. Chem. Int. Ed. Engl. 1983, 22, 907. [CrossRef]

4. Lavallo, V.; Canac, Y.; Präsang, C.; Donnadieu, B.; Bertrand, G. Stable cyclic (alkyl)(amino)carbenes as rigid or flexible, bulky, electron-rich ligands for transition-metal catalysts: A quaternary carbon atom makes the difference. Angew. Chem. Int. Ed. Engl. 2005, 44, 5705. [CrossRef]

5. Urriolabeitia, E.P. Ylide ligands. In Topics in Organometallic Chemistry; Chauvin, R., Canac, Y., Eds.; Springer: Berlin/Heidelberg, Germany, 2010; Volume 30, p. 15.

6. Kuhn, N.; Bohnen, H.; Kreutzberg, J.; Bläser, D.; Boese, R. 1,3,4,5-tetramethyl-2-methyleneimidazoline-An ylidic olefin. J. Chem. Soc. Chem. Com. 1993, 14, 1136. [CrossRef]

7. Ramirez, F.; Desai, N.B.; Hansen, B.; McKelvie, N. Hexaphenylcarbodiphosphorane, $\left(\mathrm{C}_{6} \mathrm{H}_{5}\right)_{3} \mathrm{PCP}\left(\mathrm{C}_{6} \mathrm{H}_{5}\right)_{3}$. J. Am. Chem. Soc. 1961, 83, 3539. [CrossRef]

8. Tonner, R.; Öxler, F; Neumüller, B.; Petz, W.; Frenking, G. Carbodiphosphoranes: The chemistry of divalent carbon(0). Angew. Chem. Int. Ed. 2006, 45, 8038. [CrossRef] [PubMed]

9. Marcum, J.S.; Roberts, C.C.; Manan, R.S.; Cervarich, T.N.; Meek, S.J. Chiral pincer carbodicarbene ligands for enantioselective rhodium-catalyzed hydroarylation of terminal and internal 1,3-dienes with indoles. J. Am. Chem. Soc. 2017, 139, 15580. [CrossRef] 
10. Wang, Y.; Xie, Y.; Abraham, M.Y.; Wei, P.; Schaefer III, H.F.; Schleyer, P.v.R.; Robinson, G.H. A viable anionic N-Heterocyclic dicarbene. J. Am. Chem. Soc. 2010, 132, 14370. [CrossRef] [PubMed]

11. Bestmann, H.J.; Schmidt, M. Synthesis of nitriles via the ylide anion of sodium cyanotriphenylphosphoranylidenemethanide. Angew. Chem. Int. Ed. Engl. 1987, 26, 79. [CrossRef]

12. Jordan, R.; Kunz, D. The fascinating flexibility and coordination modes of a pentamethylene connected macrocyclic CNC pincer ligand. Molecules 2021, 26, 1669. [CrossRef]

13. Dash, C.; Das, A.; Rasika Dias, H.V. Mercury(II) complexes of anionic N-heterocyclic carbene ligands: Steric effects on the backbone substituent. Molecules 2020, 25, 3741. [CrossRef] [PubMed]

14. Pellei, M.; Vallesi, R.; Bagnarelli, L.; Rasika Dias, H.V.; Santini, C. Syntheses and reactivity of new zwitterionic imidazolium trihydridoborate and triphenylborate species. Molecules 2020, 25, 3184. [CrossRef] [PubMed]

15. Pieczykolan, M.; Czaban-Józwiak, J.; Malinska, M.; Wozniak, K.; Dorta, R.; Rybicka, A.; Kajetanowicz, A.; Grela, K. The influence of various $N$-heteterocyclic carbene ligands on activity of nitro-activated olefin metathesis catalysts. Molecules 2020, $25,2282$. [CrossRef] [PubMed]

16. Peramo, A.; Abdellah, I.; Pecnard, S.; Mougin, J.; Martini, C.; Couvreur, P.; Huc, V.; Desmaële, D. A self-assembling NHC-Pdloaded calixarene as a potent catalyst for the Suzuki-Miyaura cross-coupling reaction in water. Molecules 2020, 25, 1459. [CrossRef]

17. Suresh, L.; Lalrempuia, R.; Ekeli, J.B.; Gillis-D’Hamers, F.; Törnroos, K.W.; Jensen, V.R.; Le Roux, E. Unsaturated and benzannulated $\mathrm{N}$-heterocyclic carbene complexes of titanium and hafnium: Impact on catalysts structure and performance in copolymerization of cyclohexene oxide with $\mathrm{CO}_{2}$. Molecules 2020, 25, 4364. [CrossRef]

18. Bouché, M.; Vincent, B.; Achard, T.; Bellemin-Laponnaz, S. N-heterocyclic carbene platinum(IV) as metallodrug candidates: Synthesis and ${ }^{195} \mathrm{Pt}$ NMR chemical shift trend. Molecules 2020, 25, 3148. [CrossRef]

19. Ouji, M.; Barnouin, G.; Álvarez, A.F.; Augereau, J.M.; Hemmert, C.; Benoit-Vical, F.; Gornitzka, H. Hybrid gold(I) NHC-artemether complexes to target falciparum malaria parasites. Molecules 2020, 25, 2817. [CrossRef]

20. Taakili, R.; Canac, Y. NHC core pincer ligands exhibiting two anionic coordinating extremities. Molecules 2020, 25, 2231. [CrossRef]

21. Steinert, H.; Schwarz, C.; Kroll, A.; Gessner, V.H. Towards the preparation of stable cyclic amino(ylide)carbenes. Molecules 2020, 25, 796. [CrossRef]

22. Klein, M.; Demirel, N.; Schinabeck, A.; Yersin, H.; Sundermeyer, J. Cu(I) complexes of multidentate $N, C, N-$ and $P, C, P-$ carbodiphosphorane ligands and their photoluminescence. Molecules 2020, 25, 3990. [CrossRef]

23. Authesserre, U.; Hameury, S.; Dajnak, A.; Saffon-Merceron, N.; Baceiredo, A.; Madec, D.; Maerten, E. Complexes of dichlorogermylene with phosphine/sulfoxide-supported carbone as ligand. Molecules 2021, 26, 2005. [CrossRef]

24. Zhao, L.; Chai, C.; Petz, W.; Frenking, G. Carbones and carbon atom as ligands in transition metal complexes. Molecules 2020, 25, 4943. [CrossRef]

25. Drabowicz, J.; Rzewnicka, A.; Zurawinski, R. Selenonium ylides: Syntheses, structural aspects, and synthetic applications. Molecules 2020, 25, 2420. [CrossRef] [PubMed]

26. Bloch, J.; Kradolfer, S.; Gianetti, T.L.; Ostendorf, D.; Dey, S.; Mougel, V.; Grützmacher, H. Synthesis and characterization of ion pairs between alkaline metal ions and anionic anti-aromatic and aromatic hydrocarbons with $\pi$-conjugated central seven- and eight-membered rings. Molecules 2020, 25, 4742. [CrossRef] [PubMed] 